\title{
As sereias que silenciam (ou não)
}

\author{
ADELIA BEZERRA DE MENESES ${ }^{I}$
}

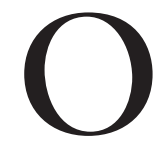

CONTO de Kafka O silêncio das sereias publicado em 1917, em plena Primeira Guerra Mundial, faz uma releitura de um episódio do canto XII da Odisseia, o encontro de Odisseu com as Sereias. Kafka se apoia no conhecimento prévio do leitor - mesmo os que não leram a Odisseia conhecem esse episódio, o mais difundido da épica e significativamente presente no folclore de várias culturas, da Lorelei nórdica à Ypupiara dos nossos indígenas. Trata-se de uma retomada do mito, uma reapropriação desse "capital cultural", como fala Bourdieu (2007) das obras clássicas que se tornaram canônicas e que continuam alimentando a civilização ocidental.

Mas a leitura desse conto kafkiano suscita um estranho sentimento de incompreensão, de confusão, de perplexidade, de desestabilidade. A gente lê e relê esse pequeno texto de uma página, ${ }^{1}$ de uma surpreendente contemporaneidade (apesar de ter sido escrito há mais de um século) e se desampara cada vez mais.

Impõem-se algumas considerações relativas à pertinência de um confronto entre um texto da Literatura moderna e um texto da Antiguidade remota - um contraponto. Pois é diante da alteridade que se evidenciam as características próprias de cada polo: confrontando o texto de Homero com um texto da modernidade, podemos saber mais sobre nós mesmos, sobre nosso mundo contemporâneo. Uma prática imantada pela ideia de Walter Benjamin (1971, p.14), segundo a qual "O problema não é interpretar a obra literária em conexão com o seu tempo, mas sim tornar evidente, no tempo que a viu nascer, o tempo que a conhece e julga, ou seja, o nosso".

Kafka transgride o mito - o que todos os autores que retomam a Odisseia fizeram e fazem - e em seguida transgride a transgressão; depois, alude a uma outra possibilidade, que talvez retome o primeiro movimento, mas a explicação aventada é irrelevante e ambígua; e ao fim da leitura, remete-se tudo a um jogo de aparências, deixando-nos perplexos. Creio ser uma função da crítica destrinçar o porquê dessa perplexidade. Deixo claro: não é a transgressão do mito, sua ruptura, que nos desconcerta; é a ruptura da ruptura, é a negação da negação, é a percepção de que, mantendo o arcabouço de um conto tradicional, evidencia-se que se tornou impossível contar, não é mais viável esse tipo de narrativa; Kafka nos retira todas as certezas, sua narrativa não é calcada em uma transmissão de experiência aproveitável; aliás, não há experiência a ser transmitida.

Mas antes de abordarmos esse item, que é o da impossibilidade de narrar, 
urge uma breve análise desse conto curto, de uma extrema condensação (o que aliás contribui significativamente para aquilo que Poe demanda de um conto: a intensidade do efeito).

Como em toda a ficção de Kafka, aqui a linguagem é extremamente clara, mas o sentido é obscuro. Cada parágrafo é cristalino, mas a interpretação do todo é desconcertante, lançando-nos num mar revolto. Começo do começo: "Prova de que até meios insuficientes - infantis mesmo - podem servir à salvação". A primeira palavra do conto, "prova”, acena com um contexto jurídico, remetendo a prova dos autos, a um aparato burocrático, na linha daquilo que a crítica kafkiana sempre levantou: um estilo cartorial. A linguagem é cristalina, objetiva, pontual; mas o sentido que o todo carreia é deslizante, fugidio, contraditório. Ao final, permanece a dúvida, não há prova de nada, prevalecerá o "jogo de aparências", não há "salvação" (seja o que for que isso signifique).

Impõe-se inescapavelmente o confronto com o texto matriz. ${ }^{2}$ No Canto XII da Odisseia, o herói conta ao rei dos Feácios a sua trabalhosa tentativa de volta a Ítaca (volta a casa, família, reino e poder). Odisseu relata inicialmente os conselhos que lhe dá Circe, advertindo-o dos perigos e preparando-o para enfrentar os terríveis entes com que se defrontará. Pois bem, na apresentação que Circe faz das sereias, fica ressaltado aquilo que ao longo dos séculos restará como a característica fulcral desses seres perigosos: voz maravilhosa, seduzem quem delas se aproxime, levando à destruição:

- Elas fascinam todos os homens que se aproximam. Se alguém, por ignorância, se avizinha e escuta a voz das Sereias, adeus regresso! Não tornará a ver a esposa e os filhos inocentes sentados alegres a seu lado, porque com seu canto melodioso, elas o fascinam, sentadas na campina em meio a montões de ossos de corpos em decomposição cobertos de peles amarfanhadas. Toca para diante: amassa cera doce de mel e veda os ouvidos de teus tripulantes para que mais ninguém as ouça. Se tu próprio as quiseres ouvir, que eles te amarrem de pés e mãos, de pé na carlinga do barco veloz, e que as pontas das cordas pendam fora de teu alcance, para te deleitares ouvindo o canto das Sereias; se insistires com teus companheiros para te soltarem, que eles te prendam com laços ainda mais numerosos. (Homero, 1993, p.142, Canto XII, vv 38-55)

Mas o que cantam as sereias, qual o conteúdo desse canto? Essa informação será dada alguns versos adiante, desta vez não mais como uma previsão ou advertência, mas como o relato de algo efetivamente acontecido. Diz o narrador Odisseu:

Estávamos à distância de um grito, avançando rapidamente, quando elas perceberam o ligeiro barco singrando perto e ergueram um canto mavioso: "Dirige-te para cá, decantado Odisseu, grande glória dos aqueus; detém o teu barco para ouvir-nos cantar. Até hoje ninguém passou vogando além daqui, sem antes ouvir a doce voz de nossos lábios e quem a ouviu partiu deleitado e mais sábio. Nós sabemos, com efeito, tudo quanto os argivos e 
troianos sofreram na extensa Tróia pela vontade dos deuses e sabemos tudo quanto se passa na terra fecunda.”

Assim diziam, entoando um belo cantar. Meu coração desejava escutá-las; eu pedia aos companheiros que me soltassem, acenando-lhes com os sobrolhos; eles, porém acurvando-se, remavam. Súbito, Perímedes e Euríloco levantaram-se e prenderam-me com laços mais numerosos e apertados. Quando, afinal eles tinham passado além das Sereias e já não ouvíamos a sua voz e o seu canto, sem demora meus leais companheiros retiraram a cera com que eu lhes vedara os ouvidos e soltaram-me dos laços. (Homero, 1993, p.145, Canto XII, vv.182-200)

Voltemos a Kafka. Quais os passos do seu conto, em confronto com o texto matriz?

1. Ulisses, que no mito original mantém os ouvidos livres e faz-se amarrar ao mastro do navio, aqui, para se defender das sereias tapou os ouvidos com cera.

2. Mas as sereias, contrariamente ao mito, "de fato" não cantaram. Ignora-se o motivo: o próprio narrador, em dúvida, propõe alternativas para explicar por que as sereias silenciam: a) "seja porque julgavam que só o silêncio poderia conseguir alguma coisa desse adversário"; b) "seja porque o ar de felicidade no rosto de Ulisses $[\ldots]$ as fez esquecer de todo e qualquer canto".

3. "No entanto" Ulisses, com os ouvidos tapados, não ouviu esse silêncio e acreditou que elas cantavam.

4. Mas as sereias, também contrariamente ao mito, "já não queriam seduzir, mas "apenas capturar, o mais longamente possível, o brilho do grande par de olhos de Ulisses". A pergunta do leitor um tanto incomodado é: capturar o olhar de alguém, ou mais precisamente, o brilho dos olhos de alguém, significaria seduzir ou ser seduzido?

5. "De resto", "talvez" Ulisses tivesse realmente percebido que as sereias haviam silenciado, e "se opôs a elas e aos deuses usando como escudo o jogo de aparências acima descrito".

O efeito sobre o leitor é bastante desarraigador; fica evidente a impossibilidade de contar, bem como a impossibilidade de se atingir algo que chamaríamos de "verdade". Mais adiante vamos destrinçar isso, apontando o caráter profético desse texto escrito há mais de um século.

O quanto esse pequeno conto é típico e característico de seu autor, poderia ser atestado por Anatol Rosenfeld, que descreve - focando, no caso, especificamente "O Processo" - o que ele chama de "arquétipo fundamental" do autor tcheco:

É conhecida esta sintaxe da frustração. As orações se iniciam com afirmações esperançosas que, em seguida, são postas em dúvida, desdobradas nas suas possibilidades, cada qual ramificando-se em novas possibilidades. Pouco a pouco a afirmação inicial é limitada por uma inundação de subjunti- 
vos e condicionais; surgem os "embora”, “de resto", "talvez”, "é verdade que", “de um lado", e "de outro lado", até ao fim não sobrar nada e tudo ser anulado. (Rosenfeld, 1976, p.236)

Importa antes dizer que a Kafka não interessou a questão daquilo que constitui fundamentalmente a sedução das sereias, que em Homero incide mais sobre o espírito do que sobre os sentidos, uma vez que elas alardeiam que sabem "tudo quanto os argivos e troianos sofreram na extensa Tróia pela vontade dos deuses"; e "tudo quanto se passa na terra fecunda" (Homero, 1993, v.191). Elas prometem, a quem as ouvir, que partirá "mais sábio". Assim, representariam uma tentação pelo saber, num recorte de conhecimento versus danação ${ }^{3}$ - o que as aproximaria da serpente bíblica no mito do Eden: como a serpente, as sereias seduzem pela promessa de um conhecimento. Se é verdade que Eva ouviu a serpente e junto com Adão comeu do fruto proibido da Árvore do Conhecimento, Odisseu, impedindo-se de ouvir, não sucumbe à tentação fatal do conhecimento (Germain, 1954 , p.382-90). Será que é isso que se embute na alusão à “salvação", presente na primeira frase do conto de Kafka citada textualmente mais acima? ["Prova de que até meios insuficientes - infantis mesmo - podem servir à salvação.”]

O Odisseu do mito, cujo epíteto fundamental é “astucioso", é um homem detentor de múltiplos recursos, "polýtropos" (de poly= muitos; e tropos = direções, meios): "multiversátil" (Homero, 2011, canto I, v.1, p.13) na tradução de Trajano Vieira. Salva-se utilizando seus múltiplos recursos, sua astúcia. O texto de Kafka sabe disso, como se lê no último parágrafo, nas últimas linhas do conto: "Diz-se que Ulisses era tão astucioso, uma raposa tão ladina, que mesmo a deusa do destino não conseguia devassar seu íntimo. Talvez ele tivesse realmente percebido [...] que as sereias haviam silenciado e se opôs a elas e aos deuses usando como escudo o jogo de aparências acima descrito". Mas ao fim de tanta astúcia se revelará o quanto a personagem kafkiana é solitária: Ulisses "se opôs a elas e aos deuses", diz o final do conto - é o herói contra todos e contra tudo, confrontando a ordem mítica. E o que restará é um jogo de aparências, seu escudo. Uma dissimulação. Diz Anatol Rosenfeld (1976, p.237) que "Kafka escreveu o mito da frustração, da impossibilidade de voltar à ordem mítica”. Esse final melancólico desautoriza a frase inicial, de que os meios "insuficientes", “infantis mesmo", usados por esse herói detentor de muitos meios teriam servido a alguma salvação.

Mas há nesse conto também uma dialética ouvir/olhar. Sabemos que essa dicotomia discrimina o "sentido" predominante, respectivamente, das culturas hebraica (audição) e grega (visão). Aqui, os ouvidos saem de foco em proveito do olhar. O Deus hebraico, esse Deus do monoteísmo, que não tem forma, que é invisível e age por meio da palavra, faz-se ouvir. Por outro lado, o mundo grego é o mundo da visão. O próprio termo "ideia” em grego vem de uma das formas verbais do verbo ver (horáo). Efetivamente a ideia é uma imagem verbal; e desse mesmo radical de horáo, do aoristo, vem eidos = forma. Mas aqui nesse 
conto, tratando-se do canto das sereias, inevitavelmente os dois sentidos (na acepção de órgãos sensoriais) estão presentes, embora o predominante seja a visão. Aliás, a crítica kafkiana sempre apontou o "caráter teatral" de seus textos. Walter Benjamin, num ensaio escrito por ocasião do décimo aniversário de sua morte fala da força do gesto, dizendo que toda a obra de Kafka seria um "código de gestos" (Benjamin, 1985, p.146) e que muitas das narrativas teriam uma natureza cênica, sendo muitas vezes o gesto o elemento decisivo, "o centro da ação" (ibidem, p.147). De fato em "O silêncio das sereias" há uma imagética forte, uma gestualidade explícita e muito intensa, um inegável poder de convocar visualmente a nossa atenção:

[...] viu os movimentos dos pescoços, a respiração funda, os olhos cheios de lágrimas, as bocas semiabertas [...]. Logo, porém, tudo deslizou do seu olhar dirigido para a distância...

Mas elas - mais belas do que nunca - esticaram o corpo e se contorceram, deixaram o cabelo horripilante voar livre no vento e distenderam as garras sobre os rochedos. (Kafka, 2002)

Volto ao movimento fundamental que se verifica no conto, e que assim se delineia: Kafka transgride o mito, nega algo, provocando em nós uma desestabilização; mas nós leitores aceitamos essa transgressão, acomodamos a nossa mente e a nossa sensibilidade a essa ruptura do mito original, e, numa recém conquistada zona de segurança, nos adaptamos a essa alteração. Mas mal se tenha feito isso, Kafka nega a transgressão: é como se o narrador nos tirasse o tapete. E lançando dúvidas sobre se as sereias silenciaram ou não, ele propõe alternativas divergentes para essa atitude ("seja porque [...] seja porque"). Ulisses não ouviu o silêncio das sereias, mas ao final, o Autor coloca isso em dúvida: talvez. Evidencia-se aqui, repito, uma impossibilidade de contar. Não apenas o foco narrativo não é confiável, mas não há "verdade" nos fatos narrados. O que resta das nossas certezas?

Uma abordagem estilística em "O silêncio das sereias", por superficial que seja, vai apontar o uso reiterado de adversativas. Ao menos três parágrafos do conto começam com uma expressão adversativa, que na versão do grande tradutor de Kafka para o português, Modesto Carone, foi diversificada (certamente por razões de sonoridade e ritmo, em português) em: entretanto ("As sereias entretanto têm uma arma ainda mais terrível que o canto"); no entanto (Ulisses, no entanto - se é que se pode exprimir assim - não ouviu o seu silêncio"); mas (Mas elas - mais belas do que nunca - [...] já não queriam seduzir, desejavam apenas capturar, o mais longamente possível, o brilho do grande par de olhos de Ulisses"). Contudo, o original alemão, nesses três casos, usa a mesma conjunção adversativa, aber (= mas). E uma adversativa, como diz com toda simplicidade o dicionário, é "Conjunção coordenativa que liga dois termos ou duas orações de função idêntica, estabelecendo, porém, uma ideia de contraste, de oposição" (Ferreira, s.d., verbete "Adversativa”). 
De todas essas afirmações - inclusive aquela que vem introduzida por um "de fato" " "E de fato, quando Ulisses chegou, as poderosas cantoras não cantaram") - que nos apresenta Kafka, em qual acreditar? Um olhar superficialmente atento aos torneios estilísticos do narrador já mostra essa maneira de fazer seguir as afirmações de um "mas" - que, como toda adversativa, postula a negação do que veio anteriormente. A “confusão como estratégia”? (Ortellado, 2020).

Anatol Rosenfeld (1976, p.227), em "Kafka e kafkianos", falando de outras obras do autor tcheco (sobretudo de "O artista da fome"), discorre sobre "a negação da negação" como algo que o caracteriza sobremaneira. Ele alude ao recurso estilístico que estabelece a figura kafkiana "das possibilidades que se anulam, da dúvida que duvida da própria dúvida, ad infinitum". O crítico aponta esse fundamental traço da obra kafkiana - da qual poderíamos dizer que, num rasgo de extraordinária contemporaneidade, indicia uma das linhas de força da nossa sociedade, em que os postulados se abalaram, em que não há verdade, tudo se relativiza, as certezas ruem. Embora o crítico não se refira ao conto em pauta, o que diz pode ser aplicado a "O silêncio das sereias" com extrema pertinência: a "dúvida que duvida da própria dúvida". O Ulisses de Kafka não oferece nada de confiável, mas o vazio da experiência; em sua solidão, numa oposição aos deuses e a tudo, ele é o herói da Modernidade.

Há mais, quanto ao foco narrativo. Depois de iniciar o conto com o termo "prova", como vimos, ele semeará a narrativa com expressões que afastam qualquer possibilidade de certeza: "diz-se que"; "talvez"; "era sabido". Não há certezas, não há fatos validados e aceitos por uma comunidade. Com as idas e vindas de uma declaração que logo na sequência é desmentida e desautorizada, onde nos apoiarmos?

A História, tanto quanto a Psicanálise e a Teoria Literária, sabe que o ponto de vista, o foco narrativo (= o narrador, aquele que conta) "formata" a realidade e, num certo sentido, a engendra. Mas aqui é o mesmo e único narrador que não mantém uma consonância com seu próprio discurso nem com sua ação: ele afirma, na sequência nega, em seguida nega a sua negação, depois duvida e retrocede. Talvez.

O conto de Kafka trata de algo que hoje poderíamos nomear de pós-verdade, ou de uma fake-narrativa. Além daquilo já apontado por Walter Benjamin, como degradação da experiência e consequente impossibilidade da narrativa enquanto veículo de experiência humana; além da derrelição dos fundamentos axiológicos que sustentariam uma comunidade, além do individualismo e da solidão que estigmatizam o conto, pode-se ver aqui também, num nível mais pontual, algo que representaria a dificuldade de se estabelecer a verdade como "consonância com os fatos". Que fatos? E sob que ótica? vergados a que ideologia?

À luz do conto kafkiano, podemos nos debruçar sobre nossa atualidade, focando declarações verbais e atuações de agentes políticos. Não é só - como 
está na moda dizer-se no jornalismo contemporâneo - na "narrativa" dos fatos políticos que afloram contradições; os atos, as decisões pragmáticas das personagens também se atropelam, se contradizem. E isso, diga-se de passagem, não só no Brasil.

“O silêncio das sereias” abrigaria os primórdios das fake-news, apontando inclusive para uma prática política que grassaria mais de um século depois, em tempos de pós-verdade, em que mandatários políticos falam, negam o que falaram, depois negam a negação e nos mergulham, perplexos nessa fake-política em uso no Brasil de 2020?

Por coincidência, neste exato momento da redação deste ensaio, uma matéria de jornal caiu sob meus olhos. Trata-se de um texto intitulado muito pertinentemente "Confusão como estratégia", de autoria de Pablo Ortellado (Folha de S.Paulo, 10 de março de 2020, p.2).

Transcrevo-o na íntegra:

\section{Confusão como estratégia}

Bolsonaro despreza os fatos e não se dá o trabalho de parecer coerente.

No começo do seu mandato o Orçamento impositivo foi apresentado como manobra do Congresso para enquadrar um presidente que não queria negociar; depois, durante a votação, virou projeto desde sempre apoiado pela família Bolsonaro, demonstrando que não existia tensão entre os Poderes; em seguida, foi vetado pelo presidente. Neste ano, quando o veto estava prestes a ser derrubado, voltou a ser chantagem do Congresso, motivo de sonoro "foda-se" pronunciado por um ministro; na semana passada, foi alvo de meticulosa negociação com os parlamentares; em seguida, a negociação, registrada no Diário Oficial, foi categoricamente negada.

A manifestação do dia 15/3 passou pelo mesmo processo. Originalmente, foi convocada para pressionar o Congresso pela prisão em segunda instância; depois, a reboque do áudio vazado do general Heleno, virou convocação anti-Congresso; diante da repercussão negativa, transformou-se em ato pró-governo; de maneira pró-ativa, o presidente compartilhou a convocação; confrontado com o fato, disse que o fez na condição de pessoa privada; alegou , em seguida, que o vídeo não era sobre a manifestação deste ano, mas sobre uma manifestação de 2015; por fim, em evento público, fez elogio à manifestação, ressalvando que era espontânea.

É atordoante a sucessão de vaivéns.

$\mathrm{O}$ que os fatos sugerem é que, por inabilidade, Bolsonaro permitiu que o Congresso mordesse parte expressiva do Orçamento discricionário do Executivo. Para não reconhecer sua incompetência política, nem a tensão crescente com o Legislativo em início de mandato, Bolsonaro fez parecer que não era contra o Orçamento impositivo, mas, sim, a favor dele. Em seguida, teve que reconhecer que a medida era ruim e que, se não negociasse, perderia o poder de alocação sobre \$ 30 bilhões. Convocou, ou articulou para que se convocasse, uma mobilização contra o Congresso para ampliar seu 
poder de negociação e desgastar as instituições. Mesmo tendo logrado uma boa negociação, disse que não negociou para manter a base mobilizada.

Chama a atenção como Bolsonaro consegue emplacar narrativas desprezando fatos e mesmo suas ações precedentes. Apenas neste episódio, o presidentes foi evasivo, mentiu e se contradisse inúmeras vezes. Seus ataques à imprensa colocam em xeque a única maneira de determinar os fatos, e sua máquina de propaganda, por meio da repetição, consegue impor as explicações mais implausíveis.

Essa confusão toda tem estratégia. (po.ortellado@gmail.com)

É um texto que prescinde de interpretação. Fala por si.

Aludi mais acima a uma modulação de "pós verdade". Pode-se objetar que essas minhas reflexões todas valeriam para a noticia e não para a narrativa enquanto gênero ficcional, matéria de mimese. Aliás, em “O narrador”, Walter Benjamin (1985a, p.203) reserva um tópico importante, exatamente para a discriminação entre notícia/informação e narrativa; e já constata que, se a arte da narrativa anda rareando, é por conta da difusão da informação. Há uma pletora de informações, e somos pobres em experiência, diz ele. Se isso era verdade na época em que Benjamin escrevia, anos 30 do século passado, atualmente a coisa só fez piorar, com as mídias digitais e com a (já quase que ultrapassada, convenhamos) Televisão como constituidoras do real. Em A cultura como espetáculo, Eduardo Subirats (1989, p.69), falando em 1989 em "simulacro medial” e em "função manipulatória da consciência individual e violação instrumental da autonomia da experiência humana", afirma que "os meios técnicos de comunicação são um instrumento de colonização da vida”. O que dizer dessa afirmação, passados trinta anos? Já se foi o tempo em que era a imagem da TV um "princípio gerador do real"; as mídias sociais a suplantaram, numa velocidade e numa intensidade estonteante. Nos tempos que correm, não apenas, como queria Walter Benjamin, a informação (aferida à notícia) tomou o lugar da experiência (relacionada à narrativa), mas a própria informação bascula, golpeada pelo seu desmentido numa escala sem precedentes, gerando um "real" provisório e sob custódia dos desmentidos. ${ }^{4}$

Importa uma observação: utilizo "narrativa”, aqui, no âmbito da Crítica Literária, no sentido de uma história contada, matéria de ficção, mimese. É de ressaltar, no entanto, o uso contemporâneo desse termo, um verdadeiro modismo, para designar o relato de fatos acontecidos, "objetivamente" noticiados em jornal, televisão, mídias sociais. Ficou na moda entre jornalistas e políticos falar de "narrativa" para a divulgação em palavras de qualquer fato, declaração ou ato de políticos (desde, por exemplo a aprovação na Câmara de algum projeto até veiculação da informação de um veto presidencial, ou declaração desastrada de algum ministro de Estado). Eliminou-se a distinção entre "narrativa" e "notícia", entre "narrativa" e "informação" - o que é extremamente sintomático.

Efetivamente, além da inequívoca estratégia das mentiras, nesse caso particular do mandatário máximo da nação e seus sequazes, evidencia-se, por outro 
lado, o avanço daquilo que Walter Benjamin observava na década de 30 do século passado, antes da Segunda Guerra mundial: a narrativa está em vias de extinção porque a experiência está em baixa: "quase nada do que acontece está a serviço da narrativa e quase tudo a serviço da informação" (Benjamin, 1985a, p.203). E é o caso de se pensar que o atual uso indiscriminado do termo "narrativa", a confusão entre "narrativa" e "informação" indicie que as narrativas, mais de oitenta anos após a reflexão de Walter Benjamin, tenham agora realmente acelerado seu processo de desaparecimento, porque, de novo, repita-se, a experiência, bem como a faculdade de intercambiar experiência, estão acabando.

Retomo no âmbito da Teoria Literária a reflexão sobre a narrativa ficcional, enfeixando a reflexão de Walter Benjamin em suas linhas fundamentais. Partindo do postulado de que a narrativa tradicional promove o intercâmbio da experiência, ele constatará que não há mais possibilidade de narrar porque não há mais "experiência” a ser transmitida. Esse é um conceito-chave de Benjamin, que ele visita em mais de uma passagem da sua obra, mas sistematicamente desenvolve em dois ensaios: - "Experiência e pobreza", de 1933 e "O narrador", de 1936. Aliás, em seu belo prefácio à edição das "Obras escolhidas" publicada pela Brasiliense em tradução de Sérgio Paulo Rouanet, Jeanne Maria Gagnebin, abordando a obra de Walter Benjamin como um todo, ressalta exatamente o que ela chama de uma "teoria da narração" benjaminiana, constelada em torno do conceito de experiência (Erfahrung) que, por sinal, diz ela, atravessa toda a sua obra. (Gagnebin, 1985, p.9)

Cabem aqui, antes de prosseguirmos na abordagem desses dois ensaios, algumas observações sobre o termo. O Dicionário de termos filosóficos de Lalande (1951, p.321) registra no verbete "Experiência": "O fato de experimentar (éprouver) algo, considerado não somente como um fenômeno transitório, mas alargando ou enriquecendo o pensamento [...]". Registre-se: "alargando ou enriquecendo o pensamento". E recorrendo a Kant, o verbete ainda precisa que a experiência fornece conhecimentos, e que é próprio dela ter um "valor de prova". Por outro lado - saindo do Dicionário filosófico e atentando para as etimologias, pode-se acrescentar que esse vocábulo vem do latim Experientia - do mesmo radical do verbo experior (cujas outras formas verbais são expertus, experiri) = fazer a tentativa, provar. E daí virá a acepção de "assumir riscos, expor-se a perigos". Perigo, do latim periculum, vem do radical de perior: experimentar, e daí, assumir riscos, expor-se a perigo, correr um perigo. De fato, quando se experimenta algo, corre-se risco: é extremamente significativo que a etimologia de experiência remeta ao mesmo radical de perigo. Algo de que os educadores e pais, mas sobretudo as mães deveriam estar cientes... E algo também que ilumina com outra luz as "aventuras" dos contos de fada e aquelas a que são submetidos os heróis de todas as grandes narrativas populares, ao fim das quais um processo de individuação estará realizado.

Voltemos a Walter Benjamin, para quem a narrativa popular é veículo de experiência humana: é nos dois textos acima referidos, "Experiência e pobre- 
za", de 1933, e "O narrador", de 1936 - que apresentam ideias semelhantes e por vezes duplicadas em sua formulação - que esse conceito-chave de Walter Benjamin, Experiência (Erfahrunng) será desenvolvido. Eu abordarei os dois ensaios como um todo. Walter Benjamin, repetindo às vezes parágrafos inteiros, retoma reflexões do texto de 1933 no texto de 1936. Com efeito, ele desenvolverá nesses escritos pensamentos básicos e complementares: a) a ideia de que ao fim da grande Guerra (a primeira) os homens voltaram mudos dos campos de batalha, "mais pobres em experiências comunicáveis, não mais ricos"; b) a ideia de que a narrativa tradicional não poderia subsistir devido às mudanças nas suas condições de produção. Além disso, apontará no texto de 1936 as características fundamentais da narrativa tradicional, em suas ligações com a sabedoria, o conselho, o senso prático, bem como sua diferenciação frente ao romance. Mas vou me ater somente àquilo que interessará para a análise do conto de Kafka, de onde parti. E a minha proposta é apontar que "O silêncio das sereias" é um conto que mostra em 1917, o mais didaticamente possível, aquilo que Walter Benjamin, duas dezenas de anos mais tarde, teorizará nesses magistrais ensaios da década de 1930, a saber, a dificuldade de narrar, ou a impossibilidade da narrativa tradicional. Ambos têm como foco principal, repita-se, a questão da degradação da experiência.

Em primeiro lugar, é curioso que ele fale do brutal empobrecimento da experiência (e consequente silenciamento dos indivíduos) aferindo-os ao fim da Primeira Guerra Mundial, sendo que os horrores da Segunda Guerra ainda estavam por vir, com o Holocausto que levaria a uma situação desraigadora impensável - da qual somos os herdeiros. Ele falará da desmoralização das experiências, no texto de 1933, que deve seu título ao empobrecimento da experiência vivenciada por sua geração - e, eu acrescentaria, pela geração de Kafka (nascido em 1883 e morto em 1924). Diz Walter Benjamin (1985b, p.115) que "nunca houve experiências mais radicalmente desmoralizadas que a experiência estratégica pela guerra de trincheiras, a experiência econômica pela inflação, a experiência do corpo pela fome, a experiência moral pelos governantes".

Pontuando a atualidade impressionante desse escrito de 1933, é o caso de nos perguntarmos agora, em 2020: a guerra com drones e aviões não pilotados, de controle remoto, assemelhando-se a um videogame macabro e asseptizado (com mutilações sangrentas e extermínio real, mas a distância) seria menos radicalmente desmoralizante que a guerra estratégica de trincheiras? E a experiência do corpo pela fome, presente e reincidente vergonhosamente no século XXI, em bolsões de pobreza, acirrada pelas "políticas de austeridade" que na realidade mascaram estratégias de exclusão social (a par com as perdas dos direitos trabalhistas, a uberização do trabalho grassando em meio ao desemprego, os etnocídios etc. etc.) - não seriam mais desmoralizantes que a experiência econômica da inflação? E, finalmente, o que dizer da "experiência moral" avacalhada pelos atuais governantes com sua boçalidade e política necrófila, em meio ao império 
das fake-news e da "confusão como estratégia" (Ortellado, 2020)? (Escrevo no Brasil, ano 2020, governo Bolsonaro, era Trump).

Mas há a segunda ideia fulcral do texto de Walter Benjamin: não é só por causa dos horrores da guerra, da qual os combatentes voltavam mudos, que a arte de contar histórias entrou em declínio: a narrativa tradicional fenece porque as suas condições de produção não existem mais. Com efeito, partindo do princípio de que é a experiência que passa de pessoa a pessoa a fonte a que recorreram todos os narradores, e que quem conta transmite um saber, diz Benjamin que a arte de narrar era alimentada ou pelo "saber das terras distantes" (veiculado pelos viajantes) ou pelo "saber do passado" (encarnado pelo trabalhador sedentário) - ambos saberes interpenetrados no sistema corporativo dos artesãos. Pois bem, tal narrativa não mais tem vez na sociedade capitalista, quando as condições de sua transmissão não existem mais. O contar histórias se dava em meio a antigas formas de trabalho manual, artesanal, um trabalho comunitário; e se inviabilizou com o advento da técnica industrial e o avançar do capitalismo, que impõe um novo ritmo e um novo conceito de tempo. E sobretudo desapareceu a comunidade de destino que aproximava o narrador do ouvinte. As análises marxistas do trabalho alienado, do esforço do operário na linha de montagem, em que ele fabrica não um objeto, mas uma peça, sempre a mesma peça, assim perdendo de vista o produto final - e tudo isso num ritmo que não é o dele, mas o da máquina - apontam as condições de opressão, desumanizadoras, que elidem qualquer veleidade de cultivar a experiência. "Uma nova forma de miséria surgiu com esse monstruoso desenvolvimento da técnica, sobrepondo-se ao homem" (Benjamin, 1985b, p.115). É essa a "pobreza" a que se refere o título do ensaio benjaminiano de 1933.

(É importante que se diga, num parênteses que, paralelamente à extinção da narrativa tradicional, emergia o romance, forma narrativa surgida com a consolidação da burguesia e que, contrariamente à dimensão necessariamente comunitária implicada na narrativa tradicional, era marcado pela individualismo: "Quem escuta uma história está em companhia do narrador; mesmo quem a lê partilha dessa companhia. Mas o leitor de um romance é solitário" (Benjamin, 1985a, p.233). E se é verdade que a narrativa tradicional tem raízes na oralidade, o romance, ligado ao livro, depende da escrita e só se viabilizou com a imprensa.)

Para desenvolver suas ideias, em Experiência e pobreza, Walter Benjamin inicia suas reflexões citando a fábula de Esopo (1999, p.187), "O lavrador e seus filhos". Trata-se da história em que um pai, no seu leito de morte, diz aos filhos que tem nas suas terras, mais precisamente no seu vinhedo, um tesouro enterrado. Após sua morte, os filhos cavam, cavam, nada descobrindo. Mas a terra assim revolvida - arada - produzirá muito, e a vindima será exuberante. Então, os filhos entenderão essa fala paterna, calcada na experiência transmitida: o valor do trabalho. 
É esse um exemplo de narrativa tradicional, aparentada ao conto de fadas, à fábula, à parábola, da grande linhagem das narrativas populares engendradas da oralidade, que vêm do fundo dos tempos. A respeito delas, diz Walter Benjamin (1985a, p.198) que "entre as narrativas escritas, as melhores são as que menos se distinguem das histórias orais contadas pelos narradores anônimos". E será nesse texto não por acaso intitulado "O narrador" que Walter Benjamin desenvolve outros tópicos correlatos da narrativa tradicional que promove o intercâmbio da experiência: o caráter utilitário que a elas subjaz, a ligação com o "conselho", a dimensão de sabedoria aí embutida. Vejamos como ele formula a questão do senso prático, declarando que a verdadeira narrativa

[...] tem sempre em si, às vezes de forma latente, uma dimensão utilitária. Sua utilidade pode consistir seja num ensinamento moral, seja numa sugestão prática, seja num provérbio ou numa norma de vida - de qualquer maneira, o narrador é um homem que sabe dar conselhos. (Benjamin, 1985a, p.200)

Esse topos do "conselho" adquire grande importância para o pensamento benjaminiano, que faz um jogo entre o substantivo alemão Rat (=conselho) e $\mathrm{o}$ adjetivo ratlos (de Rat = conselho e los = sem; etimologicamente, "sem conselho") e que significa perplexo, desesperado. A propósito de dar conselhos, diz Walter Benjamin que

[...] o conto de fada é ainda hoje o primeiro conselheiro das crianças, porque foi o primeiro da humanidade e sobrevive, secretamente, na narrativa. O primeiro narrador verdadeiro é e continua sendo o narrador de contos de fada. Esse conto sabia dar um bom conselho, quando era difícil de obter, e oferecer sua ajuda, em caso de emergência. [...] (ibidem, p.215)

E elenca exemplos:

O personagem do "tolo" nos mostra como a humanidade se fez de "tola" para proteger-se do mito; o personagem do irmão caçula mostra-nos como aumentam as possibilidades do homem quando ele se afasta da pré-história mítica; o personagem do rapaz que saiu de casa para aprender a ter medo mostra que as coisas que tememos podem ser devassadas; o personagem que socorre uma criança mostra que a natureza prefere associar-se ao homem que ao mito. (ibidem, p.215)

E sobretudo: "O conto de fadas ensinou há muitos séculos à humanidade, e continua ensinando hoje às crianças, que o mais aconselhável é enfrentar as forças do mundo mítico com astúcia e arrogância" (ibidem, p.215).

Astúcia para enfrentar as forças do mundo mítico: como não nos lembrarmos de Odisseu, cujo epíteto ao longo de toda épica é “astuto Odisseu”, e cuja saga consiste num percurso do Mythos ao Logos? Com efeito, é uma modulação de conto de fadas que encontrarmos em vários episódios das aventuras de Odisseu em seu difícil retorno a Ítaca. Fisicamente muito mais fraco do que as potências arcaicas com as quais se defronta, ele não pode jamais travar luta física com 
os poderes míticos, mas os enfrenta com a razão e com astúcia, nesse esforço de autoconservação e de individuação. E astúcia é a velha arma dos fracos contra os fortes. A tal ponto isso se verifica nas suas aventuras, que alguns críticos, como Jacqueline de Romilly, dizem que reponta aí por vezes como que uma negação do épico, uma recusa do heroico.

O protagonista vai viver aventuras que constituem, cada uma, uma espécie de relato autônomo do universo do "maravilhoso", que têm quase que uma autonomia, funcionando como contos dentro da epopeia - como se verá a seguir. São narrativas das quais se tira “experiência e conselho”. Efetivamente, o núcleo folclórico da Odisseia é tecido dessas narrativas orais, que vêm do fundo dos tempos. Amalgamando esses contos de carochinha e dando-lhes magistral unidade, Homero tem muito do contador de histórias. Importa dizer que grandes helenistas debruçaram-se sobre esse miolo folclórico da Odisseia (Page, 1988, Carpenter, 1946; Germain, 1954, Hansen, 1997), apontando o caráter de oralidade da epopeia - o que a irmanará à poesia oral de outros povos. Explica-se: uma vez que os poemas homéricos são, essencialmente, poesia oral, é lícito deduzir que a Odisseia apresenta elementos também encontráveis na literatura da oralidade de outras culturas. É assim que Page, por exemplo, em seu Raccconti popolari nell'Odissea trabalha com o "gênero" de narrativas folclóricas encontradiças em civilizações distantes, do Mediterrâneo à Índia, da Nova Zelândia à África etc. - o que justificaria, por sinal, que se aproximasse o mais famoso topos da Odisseia, o das sereias, à Mãe d'Água, Yara ou Ypupiara dos nossos indígenas, os dois últimos à margem de qualquer influência colonizadora europeia.

Por outro lado, nos capítulos "O conceito de Esclarecimento" e "Ulisses ou Mito e Esclarecimento" da Dialética do Esclarecimento, Adorno (Adorno; Horkheimer, 1986) aponta uma unidade em todas essas lendas difusas que constituem o tecido das aventuras do herói, e que estão recolhidas entre os cantos IX e XII da épica: narrativas que ocupam quatro Cantos da epopeia, totalizando aproximadamente 2.200 versos - mais de um sexto do poema. Elas versam, como já referido, sobre o confronto de Odisseu com seres fantásticos e primitivos, míticos, de uma natureza arcaica e hostil, que ele, sendo fisicamente muito mais fraco do que as forças que enfrenta, vence sabendo dominar-se e usando da astúcia. Odisseu é, nos termos da épica, como já referi, polýtropos: o herói detentor de múltiplos recursos: um trickster. A magistral interpretação que os dois autores frankfurtianos empreendem da Odisseia pode ser resumida como a viagem metafórica do homem ocidental em busca da constituição do sujeito (Adorno; Horkheimer, 1986). E cada uma das aventuras de Odisseu pode ser lida nesse registro: uma afirmação de si do herói, em confronto com forças primitivas, míticas e mágicas, que ele vence através da razão, sabendo renunciar num primeiro momento, para poder ao fim afirmar-se como um eu. Mesmo que inicialmente tenha que perder algo, tenha que renunciar, exercitando uma autorrepressão para sobreviver. A necessidade de se constituir como sujeito passa pelo imperativo de se dominar. Como quer Freud, a necessidade de passar da Natureza para 
a Cultura implica, inevitavelmente, repressão. É o que se dá, por exemplo, no episódio dos lotófagos, em que Odisseu renuncia a provar da flor do lotus, que o mergulharia num estado de felicidade e comunhão panteísta com a natureza, mas o deixaria desmemoriado, esquecido de voltar para Ítaca. Ou no caso do Cíclope Polifemo, em que o herói embebeda o gigante de um olho só para conseguir cegá-lo e depois esconde seus companheiros sob a pelagem de carneiros, para liberá-los da caverna em que estavam encerrados junto ao Cíclope, mas diz a Polifemo que se chamava "Ninguém", assim impedindo que os demais Cíclopes viessem socorrer o companheiro ferido que, quando perguntado se alguém o atacara, dizia apenas: "Ninguém me feriu"! A respeito desse caso, diz Adorno que Odisseu "faz profissão de si mesmo negando-se como Ninguém, ele salva a própria vida fazendo-se desaparecer" (Adorno; Horkheimer, 1986, p.65). Também no episódio das vacas do deus Hélio, proibidas, cuja carne os companheiros comem e todos perecem, exceto Odisseu, que delas se privara. Ou no episódio do odre dado a Odisseu por Éolo, o rei dos ventos: premidos pela curiosidade, enquanto Odisseu dorme no navio, os companheiros abrem o odre $^{6}$ e aí os ventos aprisionados saem em debandada, provocando terrível tempestade e desviando o barco de sua rota. E evidentemente, é o caso do episódio paradigmático das sereias (abordado páginas atrás), às quais Odisseu não sucumbe fazendo-se amarrar ao mastro (ao seu próprio eixo?) e tapando os ouvidos da tripulação, que remava. Como diz Adorno, "As aventuras de que Ulisses sai vitorioso são perigosas seduções que desviam o eu da trajetória de sua lógica”. E ainda, transformando Ulisses no protótipo do ser humano:

A Humanidade teve que se submeter a terríveis provações até que se formasse o eu, o caráter idêntico, determinado e viril do homem, e toda infância ainda é de certa forma a repetição disso. $\mathrm{O}$ esforço para manter a coesão do ego marca-o em todas as suas fases, e a tentação de perdê-lo jamais deixou de acompanhar a determinação cega de conservá-lo. (Adorno; Horkheimer, 1986, p.44)

Pois bem, está na hora de voltarmos a "O silêncio das sereias", o conto de Kafka de onde parti, no qual não há experiência a ser transmitida e onde se detecta a impossibilidade da narrativa tradicional. Anatol Rosenfeld, embora distante das preocupações benjaminianas com a degradação da experiência, não por acaso fala da obra de Kafka, no seu todo, como "anticontos de carochinha":

[...] porque nesta obra, embora se estabeleça nela um mundo de teor mágico-mítico, em vez de vencer a harmonia e se realizarem os desejos dos inocentes e bons, reina a desarmonia, o antagonismo radical entre aspiração e realização, a frustração em permanência. (Rosenfeld, 1976, p.231)

Mas "O silêncio das sereias" vai além de comprovar a impossibilidade da narrativa tradicional: é um conto de aguda modernidade, que mantém uma homologia estrutural com a sociedade que o gerou: ostenta uma relação Literatura $x$ Sociedade em que as linhas de força da Sociedade são discerníveis na estrutu- 
ra interna do texto literário. Ou, para falarmos com Antonio Candido (1973, p.4): aí o externo, quer dizer, o social, transforma-se em interno, quer dizer, em elemento estrutural do texto. Pois, quer queiramos, quer não, o texto é engendrado de um solo social. Mas o que é extraordinário é que Kafka aponta para tempos que viriam mais de um século depois e que estamos vivendo no nosso conturbado aqui e agora. Seria necessário apelar para o clichê de que os artistas são a "antena da raça"? Em todo o caso, pode-se dizer que a genialidade de Kafka o fez iconizar literariamente nossa conturbada contemporaneidade, com suas sereias que silenciam ou não, com seu Odisseu que talvez ouça, mas, mais propriamente, com um narrador que diz algo, nega, e em seguida nega a negação.

Reitero: nesse texto de Kafka pulsam aqueles elementos que são constituidores da contemporaneidade: as certezas que ruem, a dúvida absolutizada, a falta de referências confiáveis e que nos estruturariam, o jogo de aparências a que a realidade se reduz, a solidão álgida do indivíduo que não se coaduna mais à ordem mítica, mas se opõe a tudo e a todos. O que surpreende é que Kafka antecipa, de um século, e de uma maneira espantosa, aquilo que vige agora, no Brasil de 2020, no recorte da vida sociopolítica: a era da pós verdade, as fake-newss, da desmoralização acachapante da política esvaziada.

O que se pode finalmente dizer é que as reflexões de Walter Benjamin nos ajudam a ler o conto de Kafka; e ambos, Kafka e Benjamin, nos ajudam a "ler" o nosso tempo.

\section{Notas}

l Cf no Anexo, o conto de Kafka, "O silêncio das sereias" (Kafka, 2002).

2 Utilizarei para todas as citações da épica o texto de Homero (1993): Odisseia (Tradução Jaime Bruna). Como essa edição é em prosa e não contém numeração das passagens, para possibilitar a localização dos versos no original foi utilizada a edição bilíngue de Homero (2011, tradução, posfácio e notas de Trajano Vieira).

3 Cf o texto de minha autoria "Sereias, sedução e saber" (Meneses, 2020). Importa dizer que estes ensaios integram um Projeto de Pesquisa (do CNPq) sobre o Mito Odisseico e suas atualizações na Literatura Contemporânea.

4 Exemplificando a perplexidade externada na grande imprensa, segue, à guisa de corroboração, matéria de outro articulista do mesmo jornal, da mesma época, sobre os mesmos fatos. . Em sua coluna semanal da Folha de S.Paulo, Fernando Haddad, falando do presidente da República, refere que pesquisas da época da sua campanha eleitoral apontavam entre seus eleitores o atributo da "autenticidade", mesmo quando sabiam que ele estava mentindo. E prossegue: "Quando, recentemente, Bolsonaro ofendeu uma jornalista por atribuir-lhe a disseminação de vídeo convocatório de ato contra STF e Congresso, defendeu-se dizendo que o vídeo em questão era de 2015, sem se dar conta de que as imagens eram recentes. Desmascarado, assumiu o propósito, para em seguida, sob o pretexto do coronavirus, desaconselhar o ato, não sem antes estimulá-lo, subliminarmente, e afirmar sua legitimidade". E depois de elencar outras declarações do mesmo mandatário, o articulista cunha a expressão mentiras autênticas: "Essas mentiras autênticas são difíceis de desconstruir, pois sua justificação não está nos falsos enuncia- 
dos em si, que certamente servem de cortina de fumaça, mas nos verdadeiros comando subjacentes. O que de fato elas dizem é: 'Ataquem a imprensa! Ataquem as instituições! Ataquem a oposição!' E as matilhas virtuais reagem com seus reflexos condicionados" (Folha de S.Paulo, 14 de março de 2020, p.2).

5 Esopo, autor de fábulas, viveu na Grécia, no século VI AC - portanto, alguns séculos após Homero (convencionando-se que o autor reconhecido como "Homero" tenha colocado por escrito as narrativas épicas, que por longo tempo circularam no registro da oralidade, por volta do século IX a.C.

6 É extremamente interessante apontar o paralelo desse episódio - que trata da topos da curiosidade não refreada - com vários relatos folclóricos, como os das "1001 Noites", mas que também está presente em um conto indígena que explica a origem da noite. Trata-se da história do curumim que tinha que levar no seu barco para uma outra tribo -- e com o compromisso de não abri-lo - um coco de tucumã, com o buraquinho tampado com cera, e dentro do qual estava encerrada a noite. Mas havia barulhinhos de grilos, sapos coaxando, murmúrios ... os barulhinhos da noite. O indiozinho, vencido pela curiosidade, abre o coco - e a noite se espalha pelo mundo. Essas narrativas-irmãs - das quais não se pode absolutamente dizer que tenham tido influência recíproca, tematizam a questão de deixar-se vencer pela curiosidade. Delas se pode, como queria Walter Benjamin, tirar "experiência ou conselho". Para o texto completo da lenda indígena brasileira, ver Antonieta Dias de Moraes (1979).

\section{Referências}

ADORNO, T.; HORKHEIMER, M. O conceito de Esclarecimento; Ulisses ou mito e Esclarecimento. In:__. Dialética do Esclarecimento. 2.ed. Rio de Janeiro: Zahar, 1986.

BENJAMIN, W. Histoire Littéraire et Science de la littérature. In: Poésie et révolution. Paris: Denoël, 1971.

Magia e técnica, arte e politica. (Ensaios sobre Literatura e história da cultura). São Paulo: Brasiliense, 1985. V.1 Obras escolhidas.

O narrador. Considerações sobre a obra de Nikolai Leskov. In: Obras escolbidas. Magia e técnica, arte e política. v.1. Trad. Sergio Paulo Rouanet. Prefácio J. M. Gagnebin. São Paulo: Brasiliense, 1985a. p.197-221.

. Experiência e pobreza. In: Magia e técnica, arte e politica. Ensaios sobre Literatura e história da cultura. Trad. Sérgio Paulo Rouanet. São Paulo: Brasiliense, 1985b.

. Franz Kafka - A propósito do décimo aniversário de sua morte. In: Magia e técnica, arte e politica. Ensaios sobre Literatura e história da cultura. São Paulo: Brasiliense, $1985 \mathrm{c}$.

BOURDIEU, P. A economia das trocas simbólicas. Intr. Org e seleção por Sérgio Micelli. São Paulo: Perspectiva, 2007.

CANDIDO, A. Literatura e sociedade. São Paulo: Cia. Editora Nacional, 1973.

CARPENTER, R. Folk Tale, Fiction and Saga in the Homeric Epics. Berkeley; Los Angeles, University of California Press. 1946. (The Sather Classical Lectures, XX)

ESOPO. As fábulas de Esopo. Trad. Manuel Aveleza de Souza. Rio de Janeiro: Ática, 1999. 
FERrEIRA, A. B. de H. Novo Dicionário da Lingua Portuguesa. Rio de Janeiro: Editora Nova Fronteira, s.d.

GAGNEBIN, J. M. Walter Benjamin ou a história aberta (Prefácio). In: BENJAMIN, W. Magia e técnica, arte e politica. Ensaios sobre Literatura e história da cultura. Trad. Sérgio Paulo Rouanet. São Paulo: Brasiliense, 1985.

GERMAIN, G. Genèse de l'Odyssée: le fantastique et le sacré. Paris: Presses Universitaires de France, 1954.

HANSEN, W. Homer and the Folktale. In: MORRIS, I.; POWELL, B. (Org.) A New Companion to Homer. Leiden: Brill, 1997. p.442-62.

HOMERO. Odisseia. Trad. Jaime Bruna. São Paulo, Cultrix, 1993.

Odisseia. Trad. posfácio e notas Trajano Vieira. São Paulo: Editora 34, 2011.

KAFKA, F. O silêncio das sereias. In: . Narrativas do espólio. Trad. Modesto Carone. São Paulo: Cia. das Letras, 2002.

LALANDE, A. Vocabulaire Technique et critique de la Philosophie. Paris: Presses Universitaires de France, 1951.

MENESES, A. B. de Sereias, sedução e saber. Revista do Instituto de Estudos Brasileiro, n.75, abril de 2020 .

MORAES, A. D. de. Como a noite apareceu. In: Contos e Lendas de indios do Brasil. São Paulo: Ed. Nacional; Brasília: INL, 1979.

ORTELlADO, P. A confusão como estratégia. Folha de S.Paulo, 10 de março de 2020, p.2, Caderno A.

PAGE, D. Folktales in Homer's Odyssey. Cambridge (Massachusetts): Harvard University Press, 1973.

1988.

. Racconti popolari nell'Odissea. Trad. Roberto Velardi. [S.1.]: Liguore Editore,

ROSENFELD, A. Kafka e kafkianos. In: Texto / Contexto. 3.ed. São Paulo: Perspectiva, 1976.

SUBIRATS, E. A cultura como espetáculo. São Paulo: Nobel, 1989. (Cap. “A Janela do mundo")

RESUMO - No recorte de um estudo sobre atualizações do mito odisseico, propõe-se uma abordagem do conto "O silêncio das sereias" de Kafka, à luz das ideias de Walter Benjamin sobre a impossibilidade da narrativa tradicional, por conta da degradação da experiência. Aponta-se que nesse conto pulsam aqueles elementos que são constituidores da contemporaneidade: as certezas que ruem, a dúvida absolutizada, a falta de referências confiáveis e que nos estruturariam, o jogo de aparências a que a realidade se reduz, a solidão álgida do indivíduo. O que surpreende é que Kafka antecipa de um século e de uma maneira espantosa aquilo que vige agora, no Brasil de 2020, no recorte da vida sociopolítica: a era da pós-verdade, das fake news, da desmoralização acachapante da política, da mentira como estratégia. Assim, mostra-se que se as reflexões de Walter Benjamin nos ajudam a ler o conto de Kafka, ambos, Kafka e Benjamin, nos ajudam a "ler" o nosso tempo. 
PALAVRAS-CHAVE: Mito odisseico, Sereias, Kafka: O silêncio das sereias, Walter Benjamin e a degradação da experiência.

ABSTRACT - As part of a study of contemporary overhauls of the Odyssean myth, we propose to read Kafka's short story “The Silence of the Sirens" in light of Walter Benjamin's ideas about the impossibility of traditional narrative because of the degradation of experience. We point out that this story pulsates with the constituent elements of contemporaneity: certainties crumbling away, doubt rendered absolute, absence of reliable references that might structure us, the game of appearances to which reality has been reduced, the individual's glacial loneliness. What is surprising is that Kafka anticipates by one century, and in an astonishing way, what has now become socially and politically de rigueur in 2020 Brazil: the age of post-truth, of fake news, of the staggering demoralization of politics, of lying as a strategy. We thus hope to show that if Walter Benjamin's reflections help us to read Kafka's tale, both Kafka and Benjamin help us to "read" our own time.

KEXWORDS: Odyssean myth, Mermaids, Kafka: The Silence of the Sirens, Walter Benjamin and the degradation of experience.

Adelia Bezerra de Meneses é doutora em Teoria Literária e Literatura Comparada pela Universidade de São Paulo. Professora colaboradora voluntária do Departamento de Teoria Literária e Literatura Comparada Faculdade de Filosofia, Letras e Ciências Humanas da USP e professora aposentada do Departamento de Teoria Literária da Universidade Estadual de Campinas. Pesquisadora do CNPq. @ - adeliabm@terra.com.br / https://orcid.org/0000-0002-0906-8680.

Recebido em 14.8.2020 e aceito em 8.9.2020.

I Universidade Estadual de Campinas, Departamento de Teoria Literária, Campinas, São Paulo, Brasil. 


\section{O silêncio das sereias \\ Apêndice}

Prova de que até meios insuficientes - infantis mesmo - podem servir à salvação:

Para se defender das sereias, Ulisses tapou os ouvidos com cera e se fez amarrar ao mastro. Naturalmente - e desde sempre - todos os viajantes poderiam ter feito coisa semelhante, exceto aqueles a quem as sereias já atraíam à distância; mas era sabido no mundo inteiro que isso não podia ajudar em nada. O canto das sereias penetrava tudo e a paixão dos seduzidos teria rebentado mais que cadeias e mastro. Ulisses porém não pensou nisso, embora talvez tivesse ouvido coisas a esse respeito. Confiou plenamente no punhado de cera e no molho de correntes e, com alegria inocente, foi ao encontro das sereias levando seus pequenos recursos.

As sereias entretanto têm uma arma ainda mais terrível que o canto: o seu silêncio. Apesar de não ter acontecido isso, é imaginável que alguém tenha escapado ao seu canto; mas do seu silêncio certamente não. Contra o sentimento de ter vencido com as próprias forças e contra a altivez daí resultante - que tudo arrasta consigo - não há na terra o que resista.

E de fato, quando Ulisses chegou, as poderosas cantoras não cantaram, seja porque julgavam que só o silêncio poderia conseguir alguma coisa desse adversário, seja porque o ar de felicidade no rosto de Ulisses - que não pensava em outra coisa a não ser em cera e correntes - as fez esquecer de todo e qualquer canto.

Ulisses no entanto - se é que se pode exprimir assim - não ouviu o seu silêncio, acreditou que elas cantavam e que só ele estava protegido contra o perigo de escutá-las. Por um instante, viu os movimentos dos pescoços, a respiração funda, os olhos cheios de lágrimas, as bocas semiabertas, mas achou que tudo isso estava relacionado com as árias que soavam inaudíveis em torno dele. Logo, porém, tudo deslizou do seu olhar dirigido para a distância, as sereias literalmente desapareceram diante da sua determinação, e quando ele estava no ponto mais próximo delas, já não as levava em conta.

Mas elas - mais belas do que nunca - estivaram o corpo e se contorceram, deixaram o cabelo horripilante voar livre no vento e distenderam as garras sobre os rochedos. Já não queriam seduzir, desejavam apenas capturar, o mais longamente possível, o brilho do grande par de olhos de Ulisses.

Se as sereias tivessem consciência teriam sido então aniquiladas. Mas permaneceram assim e só Ulisses escapou delas.

De resto, chegou até nós mais um apêndice. Diz-se que Ulisses era tão astucioso, uma raposa tão ladina, que mesmo a deusa do destino não conseguia devassar seu íntimo. Talvez ele tivesse realmente percebido - embora isso não possa ser captado pela razão humana - que as sereias haviam silenciado e se opôs a elas e aos deuses usando como escudo o jogo de aparências acima descrito. 
